\title{
Research Square \\ Predictors of macular pigment and contrast threshold in normolipemic subjects aged 45-65
}

Begoña Olmedilla-Alonso ( $\square$ BOlmedilla@ictan.csic.es)

Institute of Food Science, Technology and Nutrition (ICTAN-CSIC) https://orcid.org/0000-0002-4913-

5171

\section{Elena Rodríguez-Rodríguez}

Universidad Complutense de Madrid Facultad de Farmacia

\section{Beatriz Beltrán-de-Miguel}

Universidad Complutense de Madrid Facultad de Farmacia

\section{Rocío Estévez-Santiago}

Institute of Food Science, Technology and Nutrition (ICTAN-CSIC). Universidad Francisco de Vitoria.

\section{Milagros Sánchez-Prieto}

Institute of Food Science, Technology and Nutrition (ICTAN-CSIC)

\section{Research}

Keywords: Macular pigment optical density, lutein, zeaxanthin, HDL-cholesterol, LDL-30 cholesterol, contrast threshold, dietary intake, serum concentrations

Posted Date: April 21st, 2020

DOl: https://doi.org/10.21203/rs.3.rs-22739/v1

License: (c) (i) This work is licensed under a Creative Commons Attribution 4.0 International License.

Read Full License 


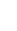

Predictors of macular pigment and contrast threshold in normolipemic subjects aged 45-65

Begoña Olmedilla-Alonso ${ }^{1}$, Elena Rodríguez-Rodríguez ${ }^{2}$, Beatriz Beltrán-de-Miguel ${ }^{3}$, Rocío EstévezSantiago ${ }^{1,4}$, Milagros Sánchez-Prieto $\mathrm{M}^{1}$

Corresponding autor: B. Olmedilla-Alonso. ICTAN-CSIC, José Antonio Novais, 10, 28040-Madrid (Spain), phone: +34 91 5492300, BOlmedilla@ictan.csic.es

\section{Abstract}

Objective: The dietary carotenoids lutein and zeaxanthin are transported in the bloodstream by lipoproteins and selectively captured in the retina where they constitute macular pigment. There are no lutein and zeaxanthin dietary intake recommendations nor desired blood/tissue concentrations for the general population. The aim of this study was to determine the lutein and zeaxanthin dietary intake, their serum concentrations, lipid profile, macular pigment optical density (MPOD) and the contrast sensitivity (CT), as visual outcome in normolipemic subjects age 45-65 $(n=101)$.

Methods: MPOD, $\mathrm{L}$ and $\mathrm{Z}$ in serum and dietary intake were determined using heterochromatic flicker photometry, high-performance liquid chromatography and 3-day food records. CT was measured with the CGT-1000 Contrast Glaretester at six stimulus sizes, with and without glare.

Results: Lutein and zeaxanthin serum concentrations (median): 0.361 and $0.078 \mu \mathrm{mol} / \mathrm{L}$. Lutein+zeaxanthin intake: $1.1 \mathrm{mg} / \mathrm{d}$ (median). MPOD: $0.34 \mathrm{du}$. Lutein+zeaxanthin intake correlates with their serum concentrations $(\rho=0.333, p=0.001)$, which in turn correlates with MPOD $(\rho=0.229, p=0.000)$ and with the fruit and vegetable consumption $(\rho=0.202, p=0.001)$, but not with the lutein+zeaxanthin dietary intake. HDL-cholesterol correlated with lutein+zeaxanthin serum $(\rho=0.253, p=0.000)$ and with CT under glare conditions ( $\rho$ range: 0.016-0.160). MPOD predictors: serum lutein+zeaxanthin, lutein+zeaxanthin/HDL-cholesterol and HDL-cholesterol $\left(\mathrm{R}^{2}=15.9 \%\right)$. CT predictors: MPOD and sex ( $\beta$ coefficients ranges: $-0.950,-0.392 ;-0.134,-0.393$, respectively). 
Conclusion: There were correlations at all points in time in this sequence between lutein+zeaxanthin

intake and the visual outcome and, HDL-cholesterol played a relevant role.

Keywords. Macular pigment optical density; lutein; zeaxanthin; HDL-cholesterol; LDLcholesterol; contrast threshold; dietary intake; serum concentrations.

\section{Introduction}

Macular pigment (MP), in the central region of the retina, is made up of lutein and zeaxanthin, major carotenoids in the human diet, and meso-zeaxanthin, which is of non-dietary origin. Of the many carotenoids present in the diet and transported in the bloodstream to tissues by lipoproteins, only these are captured by the retina where they act as blue light filters, antioxidant and anti-inflammatory agents [1], and enhance gap junctional communication [2], which, in the retina, is important for light processing [3]. An adequate nutritional status (lutein and zeaxanthin serum concentrations and macular pigment optical density [MPOD]) is associated with a lower risk of several age-related diseases, particularly agerelated eye diseases [4-6].

Lutein and zeaxanthin are among the food components that have proven to be effective in lowering the risk and /or progression of age-related macular degeneration (ARMD), a major cause of blindness in the elderly population [7]. There has recently been an increase in research looking into the potential of lutein in slowing down age-related decline and how to recover damaged cognitive functions [5]. Up to $10 \mathrm{mg}$ lutein/day has been recommended for people at risk or in the intermediates stages of age-related macular disease [8], equivalent to approx. $100 \mathrm{~g}$ spinach/day. However, there are no lutein and zeaxanthin dietary intake recomendations for general population, nor are there desired blood or tissue concentrations despite ample information rearding their status, dietary intake and biochemical markers. This is partly due to the great deal of variability in carotenoid bioavailability which depends on several host and food related factors $[9,10]$. However, reference recommendations have recently been claimed for lutein intake as regards optimal ocular health and lowering the risk of chronic eye disease as this compound meets a 
series of global criteria established for non-essential bioactive components regarding diet and health [11].

The macula is an important target tissue to consider when developing dietary recommendations for carotenoids, MPOD being the most accessible marker for xanthophyll concentration in the macula [10]. Moreover, evidences have been found supporting the effect of dietary supplements containing macular pigment carotenoids in improving visual performance in patients and in controls groups [6]. However, few studies have focused on the visual outcomes of lutein and zeaxanthin dietary intake and status (serum concentrations and MPOD) with visual outcomes (eg. contrast sensitivity, glare sensitivity, photostress recovery, visual acuity) in adults with healthy eyes [3]. In a recent study, we described age-specific correlations for the MPOD and the impact of lutein+zeaxanthin in relation to circulating lipids in apparently healthy subjects [12] and, MPOD was associated with contrast sensitivity (CT) in older subjects [13]. In this study the aim was to assess lutein and zeaxanthin dietary intake in a larger sample, their serum concentrations, lipid profile, MPOD value and contrast sensitivity in normolipemic subjects age $45-65$.

\section{7}

1

zeaxanthin (serum concentrations and MPOD) and serum lipid profile to asses their predictive value on MPOD and on visual function as determined by CT in subjects age 45 to 65.

\subsection{Participants}

101 volunteers ( 77 women and 24 men) age 45 to 65 y (mean \pm SD: $54.4 \pm 0.6$ y) were enrolled in a cross-sectional study. Participants were selected from among those interested after learning of the study through advertisements at different universities, research centers and notice boards. The inclusion of an equal number of women and men was not posible due to the lack of interest on the part of men. 
The inclusion criteria were normal cholesterolemia (upper limit $c a .6 .22 \mathrm{mmol} / \mathrm{L}$ ), BMI $\geq 20$ and

$79 \leq 30 \mathrm{~kg} / \mathrm{m} 2$, mixed diet (no avoidance of any food groups). Exclusion criteria (self reported):

80

consumption of dietary supplements, surgery for myopia (within the previous year), cataracts or macular degeneration, use of drugs or phytosterol-enriched beverages/foods to control cholesterolaemia, consumption of n-3 fatty acid-enriched food products and chronic diseases that can affect carotenoid or lipid metabolism (i.e. diabetes, cardiovascular difsease). Of the one hundred and twenty one individuals who showed their interest in participating in the study, five were excluded because of his/her BMI, three because they were taking food supplements (omega-3, lutein+zeaxanthin), three because their age, two because of statin consumption, two because of ocular chronic diseases, three without giving any explanation, one because followed a vegan diet and one because of gastric bypass.

\subsection{Procedures}

The volunteers included in this cross-sectional study underwent blood sampling, assessment of the MPOD and of the visual function, measured by the CT, and 3-day food records. The subjects were enrolled over the course of an entire year (spring and summer: 49 and during the fall and winter: 62). Blood samples were collected after overnight fast (at least 9 hours).

This study was conducted in accordance with the guidelines laid down in the Declaration of Helsinki and all procedures involving human subjects were approved by the Ethical Committee of Research with Drugs of the Hospital Universitario Puerta de Hierro Majadahonda of Madrid, Spain (acta $\mathrm{n}^{\circ}$ 03.17, dated 13 February 2017) and by the Bioethic Subcommittee- Ethics Commitee (CSIC) (dated 21 February 2017). Written informed consent was obtained from all subjects.

\subsection{Lutein, zeaxanthin and lipid analysis in blood}

Lutein and zeaxanthin levels were determined by high performance liquid chromatography (HPLC) using a system consisting of a model 600 pump, a Rheodyne injector and a 2998 photodiode array (PDA) detector (Waters, Milford, MA, USA). The system included a C30 YMC column (5 $\mu$, $250 \times 4.6 \mathrm{~mm}$ i.d.) (Waters, Wilmington, MA) with a guard column (Aquapore ODS type RP-18). The mobile phase, in a linear gradient, was metanol $(\mathrm{MeOH})$ with $0.1 \%$ triethylamine (TEA)/metyl ter-butyl 
ether (MTBE) from 95:5 to 70:30 in $25 \mathrm{~min}$, to 35:65 in $25 \mathrm{~min}$, to 95:5 in $10 \mathrm{~min}$ and maintaining this proportion for $8 \mathrm{~min}$. The flow rate was $1 \mathrm{~mL} \mathrm{min-1,} \mathrm{and} \mathrm{detection} \mathrm{was} \mathrm{performed} \mathrm{at} \mathrm{a} \mathrm{wavelenght} \mathrm{of}$ $450 \mathrm{~nm}$. All chromatograms were processed using Empower 2 software (Waters, Milford, MA, USA). Identification was carried out by comparing the retention times with those of authentic standards and on-line UV-VIS spectra.

Carotenoid extraction was performed on serum samples using a slight modification of a previously published method [14]. Briefly, $600 \mu \mathrm{l}$ of serum was added to $600 \mu \mathrm{l}$ of ethanol, vortexed and extracted twice with $1200 \mu \mathrm{l}$ of hexane: dichloromethane (5:1) stabilized with $0.1 \mathrm{~g} / \mathrm{L}$ butylated hydroxyltoluene. Organic phases were pooled, evaporated to dryness under nitrogen atmosphere and reconstituted with $200 \mu \mathrm{l}$ of a solution of metanol : methyl ter-butyl ether (1:1) and injected (50 $\mu 1)$ onto the HPLC system.

Methanol and metyl ter-butyl ether from Honeywell Research Chemicals, triethylamine and butylated hydroxytoluene from Sigma-Aldrich, hexane and dichloromethane were supplied by Lab-Scan and Panreac (Barcelona, Spain), respectively. Lutein (xanthophyll from marigold) and zeaxanthin were obtained from Sigma-Aldrich.

Standard solutions were prepared from $1 \mathrm{mg}$ of lutein and of zeaxanthin dissolved in $25 \mathrm{~mL}$ tetrahydrofuran, with $0.01 \%$ BHT in each case. The $\mathrm{E}_{1 \mathrm{~cm}}{ }^{1 \%}$ values and wavelengths used were: lutein, 2550 at $445 \mathrm{~nm}$; zeaxanthin, 2540 at $450 \mathrm{~nm}$. Working solutions were obtained from different volumes of the standard solutions dissolved in methanol:metyl ter-butyl ether $(1: 1 \mathrm{v} / \mathrm{v})$. The concentrations of the carotenoids in the curve were: $0.27-1.36 \mu \mathrm{g} \mathrm{mL}^{-1}$ for lutein $\left(\mathrm{R}^{2}=0.999\right)$ and $0.03-0.15 \mu \mathrm{g} \mathrm{mL}^{-1}$ for zeaxanthin $\left(\mathrm{R}^{2}=0.999\right)$.

Blood total cholesterol were analyzed by enzimatic assay and and high-density lipoprotein (HDL) cholesterol by catalasa assay kit (ADVIA-XPT, Siemens). The low-density lipoprotein (LDL)cholesterol level was calculated with the Friedewald equation [15]. Serum triglycerides (TG) were determined colorimetrically using the Fossati reaction with a Trinder type reaction final (GPO Trinder). Glucose was analyzed by the hexokinase method. 


\subsection{Dietary intake assessment}

Recent dietary intake was evaluated using 3-day food records involving $24 \mathrm{~h}$ recalls, one of which coincided with a weekend or holiday, carried out within a period of 7 to 10 days. The participants underwent a face-to-face encounter with a specialized interviewer for the first recall. The amounts consumed were estimated in units (fruits), portions or household servings [16]. On the basis of this information, we calculated food intake in grams/day, which served as the basis for the determination of the daily lutein and zeaxanthin intake using a database [17] included in a software application for the calculation of dietary intake of individual carotenoids [18]. To evaluate the energy intake, we employed a food composition table included in the software DIAL ${ }^{\circledR}[16]$.

\subsection{Macular pigment optical density (MPOD) assessment}

Macular pigment optical density was assessed using an MPS 9000 desktop device (Macular Pigment Screener, Elektron PLC, Cambridge, UK) that applies the principles of heterochromatic flicker photometry. The technique and reliability of this device are described in detail by van der Veen et al. [19]. The test consists of two stages for central and peripheral viewing, and the subjects were required to press a response button as soon as they detect flicker. The subjects started by fixating the central stimulus, a 1-degree central target (flicker rate is initially set to $60 \mathrm{~Hz}$ and then gradually reduced at a rate of $6 \mathrm{~Hz} \mathrm{~s}^{-1}$ ). The process was repeated for a series of green-blue luminance ratios. The observer then fixated a red $2^{\circ}$-diameter target placed $8^{\circ}$ eccentrically and a second set of data were recorded for peripheral viewing.

\subsection{Contrast threshold}

CT was measured with the CGT-1000 Contrast Glaretester (Takagi, Japan), which determined the CT by means of an automated strategy, set for 6 sizes of anular stimuli with diameters ranging from $6.3^{\circ}$ to $0.7^{\circ}$ of visual angle, with and without glare light conditions. There were 12 levels of CT, ranging from 0.01 to 0.45 . Each subject was tested monocularly for CT, once with each eye and with spectacle correction when necessary. 

specifications selected for the presentation of the stimulus were: presentation duration, 0.2 seconds; presentation interval, 2 seconds; test luminance with glare, 40,000 cd/ $\mathrm{m}^{2}$; test distance, $350 \mathrm{~mm}$. The device had 8 glare sources arranged around the stimulus that were activated automatically to assess the CT with a simultaneous glare. The test results were automatically printed out on a single graph that showed the sensitivity functions.

\subsection{Statistical analysis}

Data are expressed as means and standard deviations, medians and 95\% confidence intervals (CI). Lutein and zeaxanthin in serum and diet and TG did not follow a normal distribution (assessed by Kolmogorov-Smirnov test) and U Mann-Whitney test was used for comparison between sexes.

Correlations among variables in serum, diet, MPOD and CT were established using Spearman's rho correlation coefficient. For he analysis of the correlations among variables and for the generalized linear model we used a total sample of 145 subjects, as to the 92 from this study we incorpored data from 53 subjects, with the same characteristics, from a preliminary study previously published [12,13]. Multiple linear regression analysis was carried out using backward elimination as a model selection procedure, with MPOD as dependent variable and as independent variables the lipids concentrations, the lutein and xanthophylls expressed in relation to lipids concentrations (cholesterol, HDL-cholesterol, LDL-cholesterol, serum lutein+zeaxanthin, lutein+zeaxanthin/HDL-, lutein+zeaxanthin/LDL-, lutein+zeaxanthin/cholesterol+TG) and, fruit intake and vegetable intake.

The contrast sensitivity is the inverse of the CT. Correlations among CT and MPOD, fruit and vegetable intake and lutein+zeaxanthin/cholesterol+TG in serum were established using Spearman's rho correlation coefficient. The statistical models used were generalized linear models (TWEEDIE distribution and LINK = LOG), with CT (6 levels of stimuli, visual angle degrees) as the dependent variable and with fixed factor (sex) and covariates (serum lutein, HDL-cholesterol, LDL-cholesterol, cholesterol+ TG, MPOD and fruit +vegetables). 
All reported P-values are based on a two-sided test and compared to a significance level of 5\%.

IBM SPSS v.25 Statistics software was used.

\section{Results}

Table 1 shows subject characteristics, including the lipid concentrations as confounding factor for the interpretation of the lutein and zeaxanthin status. There were no differences in the range of age, the body mass index or blood pressure and, regarding lipid profile, only the HDL-cholesterol showed differences between sexes. Most of the subjects did not smoke (81 out of 92). Although 101 subjects participated in this study, nine of them were excluded because of serum lutein concentration above 0.63 $\mu \mathrm{mol} / \mathrm{L}$, concentration considered as that attainable by dietary means in normolipemic subjects $[4,12]$. Higher concentration is compatible with levels attained by consuming lutein food supplements, despite the fact that candidates were asked about such consumption as this was considered an exclusion criteria. This concentration represented the 92 centil in this study.

The lutein and zeaxanthin concentrations in serum and in dietary intake, MPOD, energy and fruit and vegetable consumption are shown in table 2 . Women exhibited significantly higher lutein concentrations in serum and higher MPOD levels but there were no differences in lutein and zeaxanthin intake or fruit and vegetable consumption. Serum lutein concentration related to LDL-cholesterol and to cholesterol plus TG wer also higher in women than in men.

Table 3 shows the significant correlations among serum lutein and zeaxanthin concentrations, their dietary intake and consumtion of fruit and vegetables. Serum lutein and zeaxanthin also correlated with the serum cholesterol and HDL-cholesterol, but not LDL-cholesterol. The same lipid variables correlated significantly with sex (HDL-cholesterol $\rho=0.421, p=0,000$; cholesterol $\rho=0.122, p=0.039$ ). Sex also correlated with serum concentrations of lutein $(\rho=0.216, p=0.000)$, zeaxanthin $(\rho=0.130, p=0.027)$, lutein plus zeaxanhin $(\rho=0.187, p=0.001)$, lutein plus zeaxanthin/colesterol+TG $(\rho=0.206, p=0.000)$. The highest correlations were found between the lutein+zeaxanthin intake and fruit and vegetable consumption. 
table 4. In general, these values were higher with glare than without glare. The lower the CT, the higher the contrast sensitivity level at which a subject was able to detect each spatial frequency. At most of the visual angle of the stimulus, CT correlates with the MPOD (table 5). For its part, the MPOD correlates significanty with serum lutein and zeaxanthin concentrations and with fruit and vegetable consumption, but not with the lutein+zeaxanthin dietary intake (table 5).

None of the lipid profile variables correlated significantly with MPOD. However, HDL-cholesterol did correlate with CT, only with glare, at the large and medium stimulus sizes (at 6.3 : 0.160, $\mathrm{p}=0.06$; at $4.0^{\circ}: 0.140, \mathrm{p}=0.017 ;$ at $\left.2.5^{\circ}: 0.116, \mathrm{p}=0.048\right)$.

Table 6 shows the regression model used to evaluate the predictive value of serum lutein and zeaxanthin expressed in relation to serum lipids, fruit and vegetable consumption and sex, on the MPOD value. MPOD did not show diferences between sexes in the total sample. The table only shows results that do not include zero in the confidence interval. Serum lutein plus zeaxanthin, total concentration and expressed in relation to HDL-cholesterol and HDL-cholesterol, were the main predictors of MPOD. The $\mathrm{R}^{2}$ was $15.9 \%$ for the entire sample and, broken down by sex, was $17.6 \%$ and $23.2 \%$ for women and men, respectively. If the concentration of luein and zeaxanthin expressed in relation is not considered, the predictive value is only $8.4 \%$, serum lutein being the main predictor.

Table 7 shows the results of the regression model (GELIN) used to assess the predictive value of sex, lutein serum concentration, lutein+zeaxanthin/cholesterol+TG, MPOD and fruit and vegetable consumption for CT at six visual angles of different degress, with and without glare. MPOD and sex were predictors of CT at all visual angles and the main predictors of CT were the same with and without glare, although not at all visual angles as MPOD was only at medium and smaller angles $\left(2.5^{\circ}, 1.6^{\circ}, 1.0^{\circ}\right.$ and $0.7^{\circ}$ ) and sex was not a predictor at $0.7^{\circ}$.

\section{Discussion}


degree, with the intake of lutein and zeaxanthin or the intake of their major dietary contributors. Many factors come into play here such as sex, age, body mass index, smoking status, circulating lipids and carotenoid intake patterns [10], to name few, and these should be taken into accunt in order to draw accurate comparisons between studies. It is also important to know not only how to modify MPOD by means of diet, but also the degree to which MPOD correlates to vision in apparently healthy subjects. With this study we aimed to deepen in the age-specific correlation for the MPOD with dietary and serum lutein, zeaxanthin and lipid concentrations we described previously in subjects $45-65 y[12,13]$. Subjects from the two studies had identical characteristics in terms of age, body mass index, and lipid concentration. In this study, serum lutein and zeaxanthin concentrations were higher than in the previous one (lutein median concentration: 0.361 vs $0.0242 \mu \mathrm{mol} / \mathrm{L}$ and zeaxanthin median concentration: 0.078 vs $0.048 \mu \mathrm{mol} / \mathrm{L}$ ). This could be due to the higher dietary intake of lutein+zeaxanthin (median value 1089 vs $679 \mathrm{ug} / \mathrm{d}$ ) and of the major contributors to their dietary intake (median fruit intake 323 vs 269 g/d and median vegetable intake: 342 vs $291 \mathrm{~g} / \mathrm{d})$. MPOD was slightly higher in this study (0.34 vs 0.32 $\mathrm{du}$ ) but no differences between sexes were found in the total sample.

Mean serum lutein plus zeaxanthin in this study $(0.477 \mu \mathrm{mol} / \mathrm{L})$ is above the mean $(0.330$ $\mu \mathrm{mol} / \mathrm{L}$ ) but in the $0.199-0.561 \mu \mathrm{mol} / \mathrm{L}$ range of serum lutein and zeaxanthin and the mean dietary intake of lutein and zeaxanthin $(1.5 \mathrm{mg} / \mathrm{d})$ also falls in the $0.06-4.84 \mathrm{mg} / \mathrm{d}$ range (mean $2.2 \mathrm{mg} / \mathrm{d}$ ) described in those studies [10], but is much lower than the $6 \mathrm{mg}$ of lutein/day associated with decreased risk of several chronic diseases [20,4]. The serum lutein and zeaxanthin concentration found in this study is also lower than that associated with lower risk in epidemiological studies and with improvement in physiological functions and thus, quality of life of the subjects (>0.63 $\mu \mathrm{mol} / \mathrm{L})[4]$.

Dietary intake and status markers are the first elements to be correlated in any study looking into the relationship between diet and health. Specially, regarding lutein and zeaxanthin, two status markers can be assessed: serum concentrations and MPOD as a short- and long-term markers, respectively. There was a similar / high correlation between dietary intake and serum concentrations ( $r=0.333)$ compared to 
that found in a systematic review of more than a hundred validation studies on the correlation between lutein/zeaxanthin dietary intake and plasma levels, where $r$ was 0.29 (95\%CI: 0.26, 0.32) [20]. Interestingly, the serum concentration of lutein and zeaxanthin correlated significantly with fruit consumption $(r=0.273)$ but not with the vegetable consumption, despite the fact that the amount of lutein+zeaxanthin supplied by vegetables is much greater than that supplied by fruits as shown by national surveys in Spain, for instance [21] and when assessed in small samples of adults (approximately eight times greater) [12]. This could partially be due to the fact that these xanthopylls are found in fruits in ester forms, which bioavailability is equivalent or even higher than that of free carotenoids [22]. However, dietary intake of lutein and zeaxanthin (total intake and expressed per $1000 \mathrm{Kcal}$ ) showed a higher level of correlation with vegetable as opposed to fruit consumption.

Lutein and zeaxanthin are transported by lipoproteins in the blood, which are mainly located on the surface and therefore, the transfer between lipoproteins might be easier for these xanthophylls than for the more apolar carotenoids and therefore, they could be evenly distributed between LDL and HDL fractions $[9,23]$. However, in this study serum lutein and zeaxanthin correlated with cholesterol and HDL-cholesterol, but not with LDL-cholesterol, which is compatible with the majority presence of these carotenoids in HDL-cholesterol compared to LDL-cholesterol described in several studies [25-28]. Moreover, there is a selective deposit of lutein and zeaxanthin in the eye, in the macular pigment, and it is believed to be regulated by binding proteins [9]. As in other studies with subjects of the same age group [12,29], MPOD correlated with serum lutein and zeaxanthin and also when they are expressed rin relation to lipids as reported in our previous study [12]. It also correlates with fruit and vegetable consumption $[12,30]$. We did not find any correlation between MPOD and serum cholesterol or lipoproteins, but did with lutein and zeaxanthin serum concentration expressed in relation to lipoproteins. However, a relationship between MPOD and cholesterol or lipoproteins has been reported in some studies with healthy subjects although not in others. For instance, MPOD was associated with HDLcholesterol in young healthy subjects (mean age: 23) [31] but no associations were observed in other studies in subjects with wider age ranges, 21-66 [28] and 18-75 [32]. There are differences between 
studies that may account for inconsistencies in results such as sample size, MP measurements methods and, two other aspects that are not generally considered: age group and cholesterolemia, both of which are particularly significant factors [12].

In multivariate regression analysis performed to assess the predictive value of serum lutein and zeaxanthin concentration, serum lipids, sex and fruit and vegetable consumption, only a direct association of serum lutein and zeaxanthin and an inverse associations of lutein+zeaxanthin/HDLcholesterol and of HDL-cholesterol correlated with MPOD. This association between serum xanthophylls concentration and MPOD has been widely described and the lipoprotein profile is likely to affect MP levels, although the mechanisms controlling the deposition and stabilization of MP are not fully understood [10]. In this study a high HDL-cholesterol serum concentration is associated with lower levels of MPOD and, high HDL-cholesterol is associated with a higher risk of ARMD [33,34]. However, conflicting associations between circulating lipoprotein concentrations and ARMD have been described, in part due to the changes that composition and biological properties of the HDL particles undergo under different physiological and pathological conditions [35].

Furthermore, lutein and zeaxanthin serum concentrations, MPOD and their role in ocular health should not be considered independently of circulating lipids which have an impact on their presence in the bloodstream and in tissue uptake. Although lutein and zeaxantin are both transported in HDL, a selective uptake of zeaxanthin from HDL-cholestol by retinal pigment epithelium has been described [36]. The coefficient of determination of MPOD for lutein and zeaxanthin serum concentration and when expressed in relation to HDL-cholesterol in this study was $15.9 \%$ for the entire sample $(23.2 \%$ in men and $17.6 \%$ in women), which is lower than the $29.7 \%$ obtained in the previous study [12]. However, in both cases lutein and zeaxanthin serum concentrations and also when expressed in relation with lipids were the determining factors. Therefore, for a better interpretation of the results, lutein and zeaxanthin concentrations are insufficient. They must be expressed as a function of the different lipid fractions because, as can be observed in this study, with the same lutein and zeaxanthin serum concentration 
higher HDL-cholesterol could lead to a lower lutein plus zeaxanthin and HDL-cholesterol ratio and to higher MPOD.

MPOD can optimize visual performance because of its pre-receptoral absorption of blue light and the subsequent attenuation of the effects of chromatic aberration and the adverse effect of light scatter [37-39]. Increased MPOD has been associated with improved visual function in patients with early stage AMD [40] and in control subjects [41], just as higher serum lutein and zeaxanthin was related with improved visual function in patients with cataracts [42]. However, most studies evaluating lutein and zeaxanthin intake and visual outcomes focus on MPOD as the measure of interest, although there are a number of studies with other visual outcome indicators (contrast sensitivity, glare sensitivity, photostress recovery, visual acuity) which need to be thoroughly studied in healthy individuals with a varied diet [3]. In a previous study including subjects with the same characteristics, we described MPOD and serum lutein concentration as predictors of CT, with and without glare, only in subjects within this age group but not in younger subjects (25-45 y) and found that, sex had a bearing on CT values in the older group [13]. In that study, MPOD was associated with CT, without glare, at low visual angles and, with glare, at high visual angle $\left(6.3^{\circ}\right)$. In this study, CT and serum lutein concentrations did not correlate, but we did find a stronger associations between MPOD and CT at all visual angles, without glare, and at nearly all visual angles, with glare.

\section{Conclusions}

In the time sequence between dietary intake of lutein and zeaxanthin and that of their major dietary intake contributors (mainly fruits) and the visual outcome, significant correlations were found at all points in time in these normolipemic subjects age 45-65 with no ocular diseases. Circulating lipids play an important role in this process as HDL-cholesterol (but not LDL-cholesterol) is associated with serum lutein and zeaxanthin concentration and with the CT. Serum lutein and zeaxanthin concentration related to HDL-cholesterol is a predictor of MPOD, which, in turn, determines CT in these normolipemic subjects age 45-65 who are the target population for food supplements marketed to improve vision 
quality and chronic eye disease risk reduction and which could benefit from recommendations regarding 335 carotenoid intake or desired blood or tissue concentrations to improve ocular health.

336

337

338 339 340 341 342 343 344

345 346 347 348 349 350 351 352 353 354 355 356 357 358 359

\section{Ethical Approval and consent to participate}

This study was approved by the Ethical Committee of Research with Drugs of the Hospital Universitario Puerta de Hierro Majadahonda of Madrid, Spain (acta $n^{\circ}$ 03.17, dated 13 February 2017) and by the Bioethic Subcommittee- Ethics Commitee (CSIC) (dated 21 February 2017). Written informed consent was obtained from all subjects.

\section{Consent for publication}

Not applicable.

\section{Availability of supporting data}

The datasets during and/or analysed during the current study are available from the corresponding author upon reasonable request.

\section{Competing interests}

The authors declare that they have no competing interest.

\section{Funding}

This research was funded by the Instituto de Salud Carlos III (grants PS09/00681 and PI16/01991), co-funded by ERDF/European Social Fund and by the Consejo Superior de Investigaciones Científicas (CSIC), reference P. intramural 201970E033. Open Access funding support of the publication fee was provided by the CSIC Open Access Publication Support Initiative through its Unit of Information Resources for Research (URICI). 


\section{Authors' contributions}

BOA and BBdM planning the study; Sample and material preparation, data collection and data

analysis were performed by BOA, ERR, RES, BBdM and MSP. BOA drafted the manuscript and it was 363 corrected and approved by all the authors.

\section{Acknowledgements}

The authors wish to thank Laura Barrios from the CSIC and Silvana A. Andrea Arias for their support in the statistical study and in the dietary assessment, respectively.

\section{Authors' information}

${ }^{1}$ Department of Metabolism and Nutrition, Institute of Food Science, Technology and Nutrition

${ }^{2}$ Department of Chemistry in Pharmaceutical Sciences, Faculty of Pharmacy, Complutense University 373 of Madrid, 28040 Madrid, Spain.

$374{ }^{3}$ Department of Nutrition and Food Science, Faculty of Pharmacy, Complutense University of Madrid, 37528040 Madrid, Spain.

$376{ }^{4}$ Faculty of Experimental Sciences, Francisco de Vitoria University, 28223 Pozuelo de Alarcón, 377 (Madrid), Spain.

\section{References}

[1] Johnson, E.J. Role of lutein and zeaxanthin in visual and cognitive function throughout the lifespan. Nutr Rev. 2014; 72: 605-612.

[2] Stahl, W., Sies, H. Effects of carotenoids and retinoids on gap junctional communication.

[3] Raman, G., Haslam, D., Avendano, E., Johnson, E. Lutein/zeaxanthin intake and visual outcomes in adults with healthy eyes: Qualitative gap analysis. Cogent Med. 2019; 6: 1683939. 
[4] Granado, F., Olmedilla, B., Botella, F., Simal, A., Blanco, I. Retinol and a-tocopherol in serum of 388 type 1 diabetic patients upon intensive insulin therapy: A long-term follow-up study. Nutrition 2003; 19: 389 128-132.

[5] Buscemi, S., Corleo, D., Di Pace, F., Petroni, M.L., Satriano, A., Marchesini, G. The effect of 391 lutein on eye and extra-eye health. Nutrients, 2018; 10: 1321.

[6] Stringham, J.M., Johnson, E.J., Hammond, B.R. Lutein acrossthe lifespan: from childhood cognitive performance to the aging eye and brain. Curr Dev Nutr. 2019; 3: nzz066.

[7]Age-Related Eye Disease Study Research Group. A radomized, placebo-controlled, clinical trial 395 of high-dose supplementation with vitamins $\mathrm{C}$ and $\mathrm{E}$, beta carotene, and zinc for age-related macular 396 degeneration and vision loss. AREDS Report No 8. Arch Ophhalmol. 2001; 119: 1417-1436.

[8] Huang, Y.M., Dou, H.L., Huang, F.F., Xu, X.R., Zou, Z.Y., Lin, X.M. Effect of supplemental 398 399 400 401 402 403 404 405 406 407 lutein and zeaxanthin on serum, macular pigmentation, and visual performance in patients with early age-related macular degeneration. Biomed Res Int. 2015; 564738.

[9] Rodríguez-Concepción, M., Ávalos, F.J., Bonet, M.L., Boronat, A., Gómez-Gómez, L., Hornero-Méndez, D., Limón, C., Meléndez-Martinez, A.J., Olmedilla-Alonso, B., Palou, A., Ribot, J., Rodrigo, M.J., Zacarias, L., Zhu, C. A global perspective on carotenoids: metabolism, biotechnology, and benefits for nutrition and health. Prog Lipid Res. 2018; 70: 62-93.

[10] Böhm, V., Lietz, G., Olmedilla-Alonso, B., Phelan, D., Reboul, E., Bánati, D., Borel, P., CorteReal, J., de Lera, A.R., Desmarchelier, C., Dulinska-Litewka, J., Landrier, J.F., Milisav, I., Nolan, J., Porrini, M., Riso, P., Roob, J.M., Valanou, E., Wawrzyniak, A., Winklhofer-Roob, B.M., Rühl, R., Bohn, T. From carotenoid intake to carotenoid blood and tissue concentrations - implications for dietary intake recommendations. Nutr Rev. 2020; in press.

[11] Ranard, K.M., Jeon, S., Mohn, E.S., Griffiths, J.C., Johnson, E.J., Erdman, Jr J.W. Dietary guidance for lutein: consideration for intake recommendations is scientifically supported. Eur J Nutr. 411 2017; 56(Suppl 3): 37-42. 
[12] Olmedilla-Alonso, B., Beltrán-de-Miguel, B., Estévez-Santiago, R., Cuadrado-Vives, C.

Markers of lutein and zeaxanthin status in two age groups of men and women: dietary intake, serum concentrations, lipid profile and macular pigment optical density. Nutr J. 2014; 13: 52.

[13] Estévez-Santiago, R., Olmedilla-Alonso, B., Beltrán-de-Miguel, B. Assessment of lutein and zeaxanthin status and dietary markers as predictors of the contrast threshold in 2 age groups of men and women. Nutr Res. 2016; 36: 719-730.

[14] Granado-Lorencio, F., Olmedilla-Alonso, B., Blanco-Navarro, I., Botella-Romero, F., SimalAnton, A. Assessment of carotenoid status and the relation to glycaemic control in type I diabetics: a follow-up study. Eur J Clin Nutr. 2006; 60: 1000-1008.

[15] Friedewald, W.T., Levy, R.I., Fredrickson, D.S. Estimation of the concentration of low-density lipoprotein cholesterol in plasma, without use of the preparative ultracentrifuge. Clin Chem. 1972; 18: 499-502.

[16] Ortega, R.M., Lopez-Sobaler, A.M., Andrés, P., Requejo, A.M., Aparicio, A., Molinero, L.M. DIAL Programa para evaluación de dietas y gestión de datos de alimentación. Madrid, Alce Ingenieria ${ }^{\circledR}$. 2008. https://www.alceingenieria.net/nutricion.htm

[17] Beltrán, B., Estévez, R., Cuadrado, C., Jiménez, S., Olmedilla Alonso, B. Base de datos de carotenoides para la valoración de la ingesta dietética de carotenos, xantofilas y de vitamina A; utilización en un estudio comparativo del estado nutricional en vitamina A de adultos jóvenes. Nutr Hosp. 2012; 27: 1334-1343.

[18] Estévez-Santiago, R., Beltrán-de-Miguel, B., Cuadrado-Vives, C., Olmedilla-Alonso, B. Software application for the calculation of dietary intake of individual carotenoids and of its contribution to vitamin A intake. Nutr Hosp. 2013; 28: 823-829.

[19] van der Veen, R.L.P., Berendschot, T.T.J.M., Hendrikse, F., Carden, D., Makridaki, M., Murray, I.J. A new desktop instrument for measuring macular pigment optical density based on a novel technique for setting flicker thresholds. Ophthal Phys Opt. 2009; 29: 127-137. 
Gragoudas, E.S., Haller, J., Miller, D.T. Dietary carotenoids, vitamins A, C, and E, and advanced agerelated macular degeneration. Eye disease case-control study group. JAMA, 1994; 272: 1413-1420.

[21] Burrows, T.L., Williams, R., Rollo, M., Wood, L., Garg, M.L., Jensen, M., Collins, C.E. Plasma carotenoid levels as biomarkers of dietary carotenoid consumption: A systematic review of the validation studies. J Nutr Intermediary Metab. 2015; 2: 15-64.

[22] Estévez-Santiago, R., Beltrán de Miguel, B., Olmedilla Alonso, B. Assessment of dietary lutein, zeaxanthin and lycopene intake and their sources in the National Survey of Dietary Intake in Spain (2009-2010). Int J Food Sci Nutr. 2016; 67: 305-313.

[23] Mariuti, L.R.B., Mercadante, A.Z. Carotenoid esters analysis and ocurrence: Whatdo we know so far?. Arch Biochem Biophys. 2018; 648: 36-43.

[24] Goulinet, S., Chapman, M.J. Plasma LDL and HDL subspecies are heterogenous in particle content of tocopherols and oxygenated and hydrocarbon carotenoids. relevance to oxidative resistance and atherogenesis. Arterioscler Thromb Vasc Biol. 1997; 17: 786-796

[25] Clevidence, B.A., Bieri, J.G. Association of carotenoids with human plasma lipoproteins. Methods Enzymol. 1993; 214: 33-46

[26] Cardinault, N., Abalain, J.H., Sairafi, B. Lycopene but not lutein nor zeaxanthin decreases in serum and lipoproteins in age-related macular degeneration patients. Clin Chim Acta 2005; 357: 34-42. [27] Wang, W., Connor, S.L., Johnson, E.J., Klein, M.L., Hughes, S., Connor, W.E. Effect of dietary lutein and zeaxanthin on plasma carotenoids and their transport in lipoproteins in age-related macular degeneration. Am J Clin Nutr. 2007; 85: 762-769.

[28] Loane, E., Nolan, J.M., Beatty, S. The respective relationships between lipoprotein 9profile, macular pigment optical density, and serum concentrations of lutein and zeaxanthin. Invest Ophthalmol Vis Sci. 2010; 51: 5897-5905.

[29] Burke, J.D., Curran-Celentano, J., Wenzel, A.J. Diet and serum carotenoid concentrations affect macular pigment optical density in adults 45 years and older. J Nutr. 2005; 135: 1208-1214. 
[30] Jansen, M.C.J.F., Van Kappel, A.L., Ockè, M.C., Van’t Veer, P., Boshuizen, H.C., Riboli, E., Bueno-de-Mesquita, H.B. Plasma carotenoid levels in Dutch men and women, and the relation with vegetable and fruit consumption. Eur J Clin Nutr. 2004; 58: 1386-1395.

[31] Renzi, L-M., Hammond, B.R., Dengler, M., Roberts, R. The relation between serum lipids and lutein and zeaxanthin in the serum and retina: results from cross-sectional, case control and case study designs. Lipids Health Dis. 2012; 11: 33.

[32] Broekmans, W.M.R., Berendschot, T.T.J.M., Klöpping-Ketelaars, I.A.A., de Vries, A.J., Goldbohm, R.A., Tijburg, L.B.M., Kardinaal, A.F.M., van Poppel, G. Macular pigment density in relation to serum and adipose tissue concentrations of lutein and serum concentrations of zeaxanthin. Am J Clin Nutr. 2002; 76: 595-603.

[33] Fan, Q., Maranville, J.C., Fritsche, L., Sim, X., Cheung, C.M.G., Chen, L.J., Gorski, M., Yamashiro, K., Ahn, J., Laude, A., Dorajoo, R., Lim, R.H., Teo, Y-T., Blaustein, R.O., Yoshimura, N., Park, K-H., Pang, C.P., Rai, E.S., Khor, C.C., Wong, T,Y., Runz, H., Chen, C-Y. HDL-cholesterol levels and risk of age-related macular degeneration: a multiethnic genetic study using Mendelian randomization. Internat J Epidemiol. 2017; 46: 1891-1902.

[34] Colijn, J.M., den Hollander, A.I., Demirkan, A., Cougnard-Grégoire, A., et al. Increased highdensity lipoprotein levels associated with Age-Related Macular Degeneration: Evidence from the EYERISK and European Eye Epidemiology Consortia. Ophthalmology 2019; 126: 393-406.

[35] van Leeuwen, E.N., Emri, E., Merle, B.M.J., Colijn, J.M., Kersten, E., Cougnard-Gregoire, A., Dammeier, S., Meester-Smoor, M., Pool, F.M., de Jong, E.K., Delcourt, C., Rodríguez-Bocanegra, E., Ciarnés, M., Luthert, P., Ueffing, M., Klaver, C.C.W., Nogoceke, E., den Hollander, A.I., Lengyel, I. A new perspective on lipid research in age-related macular degeneration. Prog Ret Eye Res. 2018; 67: 5686.

[36] Thomas, S-E., Harrison, E.H. Mechanisms of selective delivery of xanthophylls to retinal pigment epitelial cells by human lipoproteins. J Lipid Res. 2016; 57: 1865-1878. 
[37] Hammnod, B.R., Wooten, B.R., Snodderly, D.M. Preservation of visual sensitivity of older 489 subjects: association with macularpigment density. Invest Ophthalmol Vis Sci. 1998; 39: 397-406.

490 [38] Loskutova, E., Nolan, J., Howard, A., Beatty, S. Macular pigmentand its contribution to vision. $491 \quad$ Nutrients 2013; 5: 1962-1969.

[39] Putman, CM., Basi, C.J. Macular pigment spatial distribution effects on glare disability. $J$ 493 Optom. 2015; 8: 258-265.

[40] Richer, S., Stiles, W., Statkute, L., Pulido, J., Frankowski, J., Rudy, D., Pei, K., Tsipursky, M., 496 Nyland, J. Double-masked, placebo controlled, randomizedtrial of lutein and antioxidant supplementation in the intervention of atrophic age-related macular degeneration: the Veterans LAST 497 study (Lutein Antioxidant Supplementation Trial). Optometry 2004; 75: 216-230.

[41] Lien, E.L., Hammond, B.R. Nutritional influences on visual development and function. Prog 499 500 Retin Eye Res. 2011; 30: 188-203.

[42] Olmedilla, B., Granado, F., Blanco I., Vaquero, M. Lutein, but not a-tocopherol, supplementation 501 improves visual function in patients with age-related catarats: a 2 years double blind placebo-controlled 502 pilot study. Nutrition 2003; 19: 21-24.

503 504 505 506 507 508 509 510 


\begin{tabular}{|c|c|c|c|}
\hline & $\begin{array}{l}\text { Total sample } \\
\quad(\mathrm{n}=92)\end{array}$ & $\begin{array}{l}\text { Women } \\
(n=68)\end{array}$ & $\begin{array}{c}\text { Men } \\
(n=24)\end{array}$ \\
\hline Age (y) & $\begin{array}{c}54.5 \pm 5.8 \\
(55)\end{array}$ & $\begin{array}{c}54.6 \pm 5.9 \\
(55)\end{array}$ & $\begin{array}{c}54.1 \pm 5.4 \\
(54)\end{array}$ \\
\hline BMI $\left(\mathrm{kg} / \mathrm{m}^{2}\right)$ & $\begin{array}{c}24.8 \pm 3.1 \\
(24.3)\end{array}$ & $\begin{array}{c}24.6 \pm 3.2 \\
(24)\end{array}$ & $\begin{array}{l}25.5 \pm 2.9 \\
(26)\end{array}$ \\
\hline Glucose (mmol/L) & $\begin{array}{c}4.48 \pm 0.50 \\
\quad(4.44)\end{array}$ & $\begin{array}{c}4.42 \pm 0.44 \\
\quad(4.44)\end{array}$ & $\begin{array}{c}4.65 \pm 0.63 \\
(4.83)\end{array}$ \\
\hline Cholesterol & $\begin{array}{l}5.33 \pm 0.75 \\
\quad(5.25)\end{array}$ & $\begin{array}{l}5.38 \pm 0.76 \\
(5.26)\end{array}$ & $\begin{array}{l}5.20 \pm 0.71 \\
\quad(5.24)\end{array}$ \\
\hline HDL-cholesterol & $\begin{array}{l}1.64 \pm 0.37 \\
\quad(1.62)\end{array}$ & $\begin{array}{l}1.72 \pm 0.35^{\mathrm{a}} \\
\quad(1.76)\end{array}$ & $\begin{array}{c}1.41 \pm 0.28^{\mathrm{a}} \\
(1.41)\end{array}$ \\
\hline LDL-cholesterol & $\begin{array}{c}3.22 \pm 0.66 \\
\quad(3.18)\end{array}$ & $\begin{array}{c}3.19 \pm 0.69 \\
\quad(3.13)\end{array}$ & $\begin{array}{c}3.31 \pm 0.57 \\
\quad(3.28)\end{array}$ \\
\hline Triglycerides & $\begin{array}{c}1.00 \pm 043 \\
(0.88)\end{array}$ & $\begin{array}{l}0.98 \pm 0.44 \\
\quad(0.85)\end{array}$ & $\begin{array}{c}1.06 \pm 0.39 \\
(1.01)\end{array}$ \\
\hline Cholesterol+TG (mmol/L) & $\begin{array}{c}6.33 \pm 1.18 \\
\quad(6.13)\end{array}$ & $\begin{array}{c}6.36 \pm 1.2 \\
(6.1)\end{array}$ & $\begin{array}{c}6.26 \pm 1.1 \\
(6.25)\end{array}$ \\
\hline Diastolic pressure $(\mathrm{mm} \mathrm{Hg})$ & $\begin{array}{l}80 \pm 1 \\
(78,5)\end{array}$ & $\begin{array}{c}79 \pm 10.1 \\
(77.5)\end{array}$ & $\begin{array}{c}83.1 \pm 9 \\
(79.8)\end{array}$ \\
\hline Systolic pressure & $\begin{array}{l}125.8 \pm 17.8 \\
\quad(122)\end{array}$ & $\begin{array}{c}124 \pm 17.8 \\
\quad(120)\end{array}$ & $\begin{array}{c}131.4 \pm 17.1 \\
\quad(125.5)\end{array}$ \\
\hline
\end{tabular}

${ }^{\text {a }}$ Significant differences between sexes ( $p=0,002$ for all variables, except for HDL $p=0,000$ ) 
Table 2. Serum concentrations and dietary intake of lutein and zeaxanthin and, MPOD [mean \pm standard deviation and (median)].

\begin{tabular}{lccc}
\hline & $\begin{array}{c}\text { Total sample } \\
(\mathrm{n}=92)\end{array}$ & $\begin{array}{c}\text { Women } \\
(\mathrm{n}=68)\end{array}$ & $\begin{array}{c}\text { Men } \\
(\mathrm{n}=24)\end{array}$ \\
\hline Serum concentrations & & & \\
\hline Lutein $(\mu \mathrm{mol} / \mathrm{L})$ & $0.37 \pm 0.12$ & $0.39 \pm 0.11^{\mathrm{a}}$ & $0.33 \pm 0.11^{\mathrm{a}}$ \\
& $(0.36)$ & $(0.37)$ & $(0.32)$ \\
\hline Zeaxanthin $(\mu \mathrm{mol} / \mathrm{L})$ & $0.10 \pm 0.05$ & $0.10 \pm 0.04$ & $0.11 \pm 0.06$ \\
& $(0.08)$ & $(0.10)$ & $(0.12)$ \\
\hline Lutein+zeaxanthin/cholesterol+TG & $0.09 \pm 0.03$ & $0.09 \pm 0.03$ & $(0.08)$ \\
( $\mu$ mol/mmol) & $(0.09)$ & $(0.09)$ & \\
\hline Dietary intake & & & $1664 \pm 1939$ \\
\hline Lutein+zeaxanthin $(\mu \mathrm{g} /$ day) & $1503 \pm 1433$ & $1446 \pm 1219$ & $(1177)$ \\
& $(1089)$ & $(1037)$ & $677 \pm 819$ \\
& $724 \pm 677$ & $741 \pm 626$ & $(459)$ \\
\hline Lutein+zeaxanthin / 1000 kcal & $(520)$ & $(548)$ & $400 \pm 334$ \\
& $375 \pm 281$ & $366 \pm 261$ & $(240)$ \\
\hline Fruit intake $(\mathrm{g} /$ day) & $(323)$ & $(336)$ & $344 \pm 173$ \\
& $342 \pm 150$ & $342 \pm 143$ & $(348)$ \\
\hline Vegetable intake & $(342)$ & $(342)$ & $744 \pm 410$ \\
& $717 \pm 339$ & $707 \pm 313$ & $(649)$ \\
\hline Fruit+vegetable intake & $(650)$ & $(654)$ & $2550 \pm 176^{\mathrm{a}}$ \\
& $2136 \pm 299$ & $1990 \pm 167^{\mathrm{a}}$ & $(2503)$ \\
\hline Energy intake $(k c a l / d)$ & $(2073)$ & $(1960)$ & $0.31 \pm 0.13^{\mathrm{a}}$ \\
& $0.34 \pm 0.13$ & $0.35 \pm 0.13{ }^{\mathrm{a}}$ & $(0.31)$ \\
\hline Macular pigment optical density & $(0.34)$ & $(0.36)$ & \\
(density units) & & & \\
(n=184 eyes) & & &
\end{tabular}

${ }^{\text {a }}$ Significant differences between sexes for serum lutein $(p=0,019)$, serum lutein/LDL-cholesterol 
Table 3. Statistically significant correlations (Spearman's rho, ( $p$ value) between lutein, zeaxantin, lipids and major food sources for dietary intake and serum concentrations.

\begin{tabular}{|c|c|c|c|c|c|c|c|}
\hline & \multicolumn{5}{|c|}{ Serum } & \multicolumn{2}{|r|}{ Diet } \\
\hline & Lutein & Zeax. & Lutein+Zeax. & $\begin{array}{l}\text { Lutein+Zeax. } \\
\text { /chol.+TG }\end{array}$ & Cholesterol & Lutein+Zeax. & Lutein+zeax./1000 kcal \\
\hline Serum concentrations & & & & & & & \\
\hline Cholesterol & $\begin{array}{c}0.213 \\
(0.010)\end{array}$ & & $\begin{array}{l}0.178 \\
(0.002)\end{array}$ & & & & \\
\hline HDL-cholesterol & $\begin{array}{c}0.274 \\
(0.001)\end{array}$ & $\begin{array}{c}0.132 \\
(0.024)\end{array}$ & $\begin{array}{l}0.253 \\
(0.000)\end{array}$ & & & & \\
\hline Dietary intake & & & & & & & \\
\hline Lutein+Zeax. & $\begin{array}{c}0.363 \\
(0.000)\end{array}$ & & $\begin{array}{c}0.333 \\
(0.001)\end{array}$ & $\begin{array}{l}0.358 \\
(0.000)\end{array}$ & & & \\
\hline Lutein+Zeax./1000 kcal & $\begin{array}{c}0.376 \\
(0.000)\end{array}$ & & $\begin{array}{c}0.331 \\
(0.000)\end{array}$ & $\begin{array}{l}0.366 \\
(0.000)\end{array}$ & & & \\
\hline Fruit & $\begin{array}{c}0.273 \\
(0.001)\end{array}$ & $\begin{array}{c}0.203 \\
(0.014)\end{array}$ & $\begin{array}{c}0.280 \\
(0.001)\end{array}$ & $\begin{array}{l}0.324 \\
(0.000)\end{array}$ & $\begin{array}{l}-0.216 \\
(0.009)\end{array}$ & $\begin{array}{c}0.353 \\
(0.001)\end{array}$ & $\begin{array}{c}0.395 \\
(0.000)\end{array}$ \\
\hline Vegetable & & & & & & $\begin{array}{c}0.481 \\
(0.000)\end{array}$ & $\begin{array}{c}0.504 \\
(0.000)\end{array}$ \\
\hline Fruit+vegetable & $\begin{array}{c}0.281 \\
(0.001)\end{array}$ & $\begin{array}{c}0.195 \\
(0.019)\end{array}$ & $\begin{array}{c}0.281 \\
(0.000)\end{array}$ & $\begin{array}{l}0.306 \\
(0.000)\end{array}$ & & $\begin{array}{c}0.482 \\
(0.000)\end{array}$ & $\begin{array}{c}0.525 \\
(0.000)\end{array}$ \\
\hline
\end{tabular}




\begin{tabular}{|c|c|c|c|c|c|c|}
\hline & \multicolumn{2}{|c|}{ Total sample } & \multicolumn{2}{|c|}{ Women } & \multicolumn{2}{|c|}{ Men } \\
\hline $\begin{array}{l}\text { Visual angle of } \\
\text { the estimulus }\left({ }^{\circ}\right)\end{array}$ & Without glare & With glare & Without glare & With glare & Without glare & With glare \\
\hline 6.3 & $\begin{array}{l}0.019 \pm 0.011 \\
(0.014) \\
{[0.017,0.020]}\end{array}$ & $\begin{array}{l}0.020 \pm 0.016 \\
(0.014) \\
{[0.018,0.022]}\end{array}$ & $\begin{array}{l}0.020 \pm 0.012 \\
(0.014) \\
{[0.020,0.021]}\end{array}$ & $\begin{array}{l}0.021 \pm 0.016 \\
(0.014) \\
{[0.018,0.023]}\end{array}$ & $\begin{array}{l}0.016 \pm 0.008 \\
(0.014) \\
{[0.015,0.018]}\end{array}$ & $\begin{array}{l}0.016 \pm 0.007 \\
(0.014) \\
{[0.015,0.018]}\end{array}$ \\
\hline 4.0 & $\begin{array}{l}0.026 \pm 0.021 \\
(0.020) \\
{[0.023,0.029]}\end{array}$ & $\begin{array}{l}0.024 \pm 0.020 \\
(0.020) \\
{[0.023,0.028]}\end{array}$ & $\begin{array}{l}0.029 \pm 0.026 \\
(0.020) \\
{[0.025,0.033]}\end{array}$ & $\begin{array}{l}0.029 \pm 0.025 \\
(0.020) \\
{[0.025,0.033]}\end{array}$ & $\begin{array}{l}0.019 \pm 0.010 \\
(0.014) \\
{[0.017,0.021]}\end{array}$ & $\begin{array}{l}0.019 \pm 0.011 \\
(0.014) \\
{[0.017,0.022]}\end{array}$ \\
\hline 2.5 & $\begin{array}{l}0.037 \pm 0.034 \\
(0.030) \\
{[0.032,0.042]}\end{array}$ & $\begin{array}{l}0.042 \pm 0.036 \\
(0.030) \\
{[0.036,0.047]}\end{array}$ & $\begin{array}{l}0.041 \pm 0.039 \\
(0.030) \\
{[0.036,0.047]}\end{array}$ & $\begin{array}{l}0.046 \pm 0.041 \\
(0.030) \\
{[0.040,0.052]}\end{array}$ & $\begin{array}{l}0.029 \pm 0.017 \\
(0.030) \\
{\left[\begin{array}{ll}0.050 & 0.032\end{array}\right]}\end{array}$ & $\begin{array}{l}0.033 \pm 0.023 \\
(0.030) \\
{[0.029,0.038]}\end{array}$ \\
\hline 1.6 & $\begin{array}{l}0.067 \pm 0.054 \\
(0.040) \\
{[0.059,0.074]}\end{array}$ & $\begin{array}{l}0.078 \pm 0.066 \\
(0.060) \\
{[0.068,0.087]}\end{array}$ & $\begin{array}{l}0.072 \pm 0.060 \\
(0.060) \\
{[0.063,0.080]}\end{array}$ & $\begin{array}{l}0.085 \pm 0.076 \\
(0.060) \\
{[0.074,0.096]}\end{array}$ & $\begin{array}{l}0.053 \pm 0.040 \\
(0.040) \\
{[0.045,0.045]}\end{array}$ & $\begin{array}{l}0.060 \pm 0.039 \\
(0.060) \\
{[0.053,0.068]}\end{array}$ \\
\hline 1.0 & $\begin{array}{l}0.147 \pm 0.100 \\
(0.110) \\
{[0.133,0.162]}\end{array}$ & $\begin{array}{l}0.176 \pm 0.114 \\
(0.160) \\
{[0.159,0.195]}\end{array}$ & $\begin{array}{l}0.156 \pm 0.112 \\
(0.110) \\
{[0.140,0.172]}\end{array}$ & $\begin{array}{l}0.187 \pm 0.127 \\
(0.160) \\
{[0.169,0.206]}\end{array}$ & $\begin{array}{l}0.120 \pm 0.084 \\
(0.110) \\
{[0.103,0.137]}\end{array}$ & $\begin{array}{l}0.144 \pm 0.095 \\
(0.110) \\
{[0.125,0.163]}\end{array}$ \\
\hline 0.7 & $\begin{array}{l}0.307 \pm 0.150 \\
(0.320) \\
{[0.285,0.329]}\end{array}$ & $\begin{array}{l}0.352 \pm 0.140 \\
(0.320) \\
{[0.332,0.372]}\end{array}$ & $\begin{array}{l}0.310 \pm 0.159 \\
(0.320) \\
{[0.287,0.333]}\end{array}$ & $\begin{array}{l}0.348 \pm 0.150 \\
(0.320) \\
{[0.327,0.370]}\end{array}$ & $\begin{array}{l}0.269 \pm 0.150 \\
(0.230) \\
{[0.239,0.299]}\end{array}$ & $\begin{array}{l}0.313 \pm 0.155 \\
(0.320) \\
{[0.282,0.344]}\end{array}$ \\
\hline
\end{tabular}

Values are expressed as means $\pm \mathrm{SD}$, (medians). 
Table 5. Statistically significant correlations (Spearmn's rho, (pvalue) between lutein, zeaxanthin and major food sources for their intake in serum and diet with MPOD (two eyes/subject).

\begin{tabular}{lll}
\hline & \multicolumn{1}{l}{ MPOD } \\
\hline Lutein (serum) & $0.226(0.000)$ \\
\hline Zeaxanthin (serum) & $0.177(0.003)$ \\
\hline Lutein+zeaxanthin (serum) & $0.229(0.000)$ \\
\hline Lutein+zeax./chol.+TG & $0.165(0.005)$ \\
\hline Lutein+zeax./LDL & $0.159(0.007)$ \\
\hline Lutein+zeax./HDL & $0.149(0.011)$ \\
\hline & & \\
\hline Fruit intake & 0.156 & $(0.008)$ \\
\hline Vegetable intake & 0.184 & $(0.002)$ \\
\hline Fruit +vegetable intake & 0.202 & $(0.001)$ \\
\hline Contrast threshold-visual angle of the stimulus & & \\
\hline Without glare & & \\
\hline 6.3 & -0.121 & $(0.039)$ \\
\hline 4.0 & -0.160 & $(0.006)$ \\
\hline 2.5 & -0.182 & $(0.002)$ \\
\hline 1.6 & -0.205 & $(0.000)$ \\
\hline 1.0 & -0.193 & $(0.001)$ \\
\hline 0.7 & -0.201 & $(0.001)$ \\
\hline With glare & & \\
\hline 6.3 & -0.135 & $(0.022)$ \\
\hline 4.0 & & \\
\hline 2.5 & -0.155 & $(0.008)$ \\
\hline 1.6 & -0.152 & $(0.009)$ \\
\hline 1.0 & -0.160 & $(0.006)$ \\
\hline 0.7 & -0.142 & $(0.015)$ \\
\hline & &
\end{tabular}




\begin{tabular}{lccc}
\hline & $\boldsymbol{\beta}(\mathbf{D E})$ & $\boldsymbol{p}$ & $\mathbf{9 5 \%} \mathbf{C I}$ \\
\hline Constant & $0.706(0.109)$ & 0.000 & $0.492,0.919$ \\
\hline Lutein +zeaxanthin (serum) & $0.023(0.004)$ & 0.000 & $0.015,0.031$ \\
\hline Lutein+zeaxanthin/HDL & $-0.907(0.214)$ & 0.000 & $-1.328,-0.485$ \\
\hline HDL-cholesterol & $-0.00(0.002)$ & 0.000 & $-0.009,-0.003$
\end{tabular}

CI: confidence interval. 


\begin{tabular}{|c|c|c|c|c|c|c|c|}
\hline \multirow[b]{2}{*}{$\begin{array}{l}\text { Visual angle of } \\
\text { the estimulus }\left(^{\circ}\right)\end{array}$} & & \multicolumn{3}{|c|}{ Without glare } & \multicolumn{3}{|c|}{ With glare } \\
\hline & & $\beta(\mathrm{DE})$ & $p$ & $95 \% \mathrm{CI}$ & $\beta(\mathrm{DE})$ & $p$ & $95 \% \mathrm{CI}$ \\
\hline \multirow[t]{3}{*}{6.3} & Intercept & $-3.801(0.074)$ & 0.000 & $-3.946,-3.656$ & $-3.740(0.080)$ & 0.000 & $-3.897,-3.583$ \\
\hline & Sex & $-0.186(0.061)$ & 0.002 & $-0.306,-0.066$ & $-0.254(0.067)$ & 0.000 & $-0.386,-0.122$ \\
\hline & MPOD & $-0.392(0.202)$ & 0.052 & $-0.788,0.003$ & $-0.395(0.218)$ & 0.070 & $-0.823,0.032$ \\
\hline \multirow[t]{3}{*}{4.0} & Intercept & $-3.379(0.094)$ & 0.000 & $-3.563,-3.195$ & $-3.415(0.092)$ & 0.000 & $-3.596,-3.235$ \\
\hline & Sex & $-0.393(0.078)$ & 0.000 & $-0.547,-0.240$ & $-0.392(0.078)$ & 0.000 & $-0.545,-0.238$ \\
\hline & MPOD & $-0.513(0.260)$ & 0.048 & $-1.022,-0.005$ & $-0.393(0.252)$ & 0.119 & $-0.888,0.101$ \\
\hline \multirow[t]{3}{*}{2.5} & Intercept & $-2.955(0.101)$ & 0.000 & $-3.154,-2.757$ & $-2.866(0.099)$ & 0.000 & $-3.062,-2.671$ \\
\hline & Sex & $-0.359(0.085)$ & 0.000 & $-0.526,-0.193$ & $-0.309(0.084)$ & 0.000 & $-0.475,-0.144$ \\
\hline & MPOD & $-0.723(0.279)$ & 0.010 & $-1.270,-0.175$ & $-0.677(0.273)$ & 0.013 & $-1.212,-0.143$ \\
\hline \multirow[t]{3}{*}{1.6} & Intercept & $-2.332(0.101)$ & 0.000 & $-2.531,-2.134$ & $-2.177(0.100)$ & 0.000 & $-2.373,-1.981$ \\
\hline & Sex & $-0.292(0.085)$ & 0.001 & $-0.459,-0.126$ & $-0.331(0.085)$ & 0.000 & $-0.499,-0.164$ \\
\hline & MPOD & $-0.950(0.279)$ & 0.001 & $-1.496,-0.404$ & $-0.890(0.276)$ & 0.001 & $-1.430,-0.350$ \\
\hline \multirow[t]{3}{*}{1.0} & Intercept & $-1.556(0.098)$ & 0.000 & $-1.748,-1.365$ & $-1.444(0.097)$ & 0.000 & $-1.633,-1.255$ \\
\hline & Sex & $-0.257(0.082)$ & 0.002 & $-0.417,-0.096$ & $-0.260(0.081)$ & 0.001 & $-0.419,-0.102$ \\
\hline & MPOD & $-0.938(0.270)$ & 0.001 & $-1.467,-0.410$ & $-0.712(0.264)$ & 0.007 & $-1.230,-0.194$ \\
\hline \multirow[t]{3}{*}{0.7} & Intercept & $-0.955(0.085)$ & 0.000 & $-1.121,-0.789$ & $-0.926(0.077)$ & 0.000 & $-1.076,-0.776$ \\
\hline & Sex & $-0.134(0.070)$ & 0.055 & $-0.272,0.003$ & $-0.103(0.062)$ & 0.097 & $-0.225,0.019$ \\
\hline & MPOD & $-0.672(0.231)$ & 0.004 & $-1.125,-0.219$ & $-0.394(0.208)$ & 0.058 & $-0.801,0.013$ \\
\hline
\end{tabular}

